\title{
The political psychology of (de)securitization: place-making strategies in Denmark, Sweden, and Canada
}

\author{
Catarina Kinnvall \\ Department of Political Science, Lund University, Box 52, 22100 Lund, Sweden; \\ e-mail: catarina.kinnvall@svet.lu.se
}

\section{Paul Nesbitt-Larking}

Department of Political Science, Huron University College, The University of Western Ontario, 1349 Western Road, London, Ontario N6G 1H3, Canada; e-mail: pnesbitt.uwo.ca

Received 3 November 2008; in revised form 18 February 2010; published online 18 August 2010

\begin{abstract}
In this article we demonstrate how both state structures and collective agencies contribute to patterns of securitization and, in so doing, reconfigure conceptions of space and place. Focusing on the life-chances of Muslim minority populations in Denmark, Sweden, and Canada, we begin by establishing how experiences of empire and colonization have shaped dominant regimes of citizenship and multiculturalism. Analyzing responses to the Danish newspaper publication of the 'Mohammed cartoons', we illustrate the dynamics of place making that are operative in the political psychology of securitization. Our analysis illustrates the cosmopolitical and dialogical character of Canadian multiculturalism and how such a regime facilitates a politics of space that is distinct from the cartographies of imperialism that inform place making in Denmark and, to a lesser extent, Sweden.
\end{abstract}

\section{Introduction}

As in many other parts of the world, residents in the metropolitan and multicultural areas of Copenhagen in Denmark, Malmö in Sweden, and the Greater Toronto Area in Canada, daily experience the growing complexities and hybridizations of borders and identities, of interior and exterior, and of spaces and faces. The experiential borders of 'Danishness', 'Swedishness', and 'Canadianness' are smudging and eroding. Global cyberflows of information and capital, substantial waves of immigration, and a more visible and thriving multiculturalism have challenged much of what was previously taken for granted in defining societal and proprietorial borders. It is, in fact, less and less viable to construct place-based realities on the scale of national-level institutions and social organizations. The new dynamism in the public sphere is located in the microsociology and psychology of neighborhood morphology, housing allocations, the politics of schooling, interpersonal encounters, food habits, dress codes, and other similar signifiers. As we explain below, the experiential scope of such ostensibly localized place-based identifiers is in fact 'glocalized' (Robertson, 1995). Glocalization is constituted by the practices of local agents as they construct meanings, negotiate identities, and reproduce institutional forms within the context of globalization. Glocalization is practiced dialectically as agents invoke, claim, refine, and hybridize phenomenal elements whose territory, place, scale, and network swoop from the local to the global, often apprehended in the same experiential moment. Although glocalization is a matter of deliberative agency, it is not entirely a matter of voluntarism. Certain glocalizing projects are structurally more feasible than others, and some come with greater privilege and prestige than others.

In this article we discuss this sociopsychological place-making as a process of 'securitization' among both majority and minority communities. Our conception of securitization develops the work of the Copenhagen School (Buzan et al, 1998) and defines securitization as the social construction of an existential threat that 
successfully justifies extraordinary political measures. To securitize an issue that had not previously been viewed as a security threat is to challenge the state to commit greater resources to solving problems associated with it. To desecuritize an issue means to remove it from the realm of existential survival, thus making it easier to resolve through cooperative and/or routine means of problem solving in civil society (Sheehan 2005, page 54). Thus, the very invocation and attempted reassertion of borders, sovereign powers, and state apparatuses is evidence of bids for securitization, not merely on the part of majorities but also minorities.

Our theoretical orientation applies elements of structurationist analysis (Giddens, 1984) to the emergence of place-making strategies among Muslim minorities in Denmark, Sweden, and Canada. We demonstrate how both structures and collective agency contribute to patterns of (de)securitization. The life-chances and statuses of Muslim minorities are established in three distinct regimes of citizenship, which are themselves grounded in histories of empire and colonization. We discuss this colonial legacy and set out the nature of these three regimes in the first two sections of the article. Such regimes constitute formative forces in preferring and privileging typical place-making strategies on the part of Muslim minorities. Of central importance are the specific regimes of multiculturalism adopted in each political society. In order to understand the dynamics of place making, we require a political psychology of securitization. The praxis of such place-making strategies is evident in the responses to a common global event: the September 2005 publication of the Mohammed cartoons in Denmark. This event substantially destabilized both majority and minority Muslim populations and led to a series of actions and reactions related to bids to securitize and desecuritize. We use the example of the Mohammed cartoons to illustrate how different regimes of citizenship affect and instigate different responses in securitizing practices. In the third section of the article we analyze the political psychology of (de)securitization in each of the three societies, focusing in particular on the place-making strategies that typify each country's responses to the Mohammed cartoon and other associated crises. Our analysis draws upon a range of secondary sources, notably the published responses of political and community leaders to the Mohammed cartoon crisis, as well as data from sixty-two in-depth interviews we conducted with Muslims in Denmark (fifteen), Sweden (thirteen), and Canada (thirty four).

\section{Empire and colonization: reconfiguring space and place}

As with much in the late modern experience, the growing complexity of borders and margins can be celebrated as an expression of creative opportunity or feared as an existential threat. Hall (1992) recalls the powerful Eurocentric intellectual tradition that regards human diversity as fixed and immutable differences among types of human beings. Under the influence of nationalist ideas that emerged in the era of imperialism and colonialism, this tradition resulted in notions of political societies as singular, bordered, sovereign, and internally integrated. Within these realms, people were basically the same, while outside they were entirely different-they were the 'Other' and essentialized as such (Calhoun, 1995, page 44). A common reaction against the erosion of clear boundaries and the onset of global migrations and flows has been a series of moral panics, seeking to reassert clear lineages of ethnic heritage and demarcations of cultural homogeneity both in Western Europe and, to a lesser extent, in Canada. Those who lament the loss of the mythic past of ethnoreligious solidity find it difficult to come to terms with a society that is no longer (and in fact never was) monocultural and monoracial. Given the refusal of majorities in Europe (and their reticence in Canada) to open the door to sincere and egalitarian regard of the newcomer and to include them as fully entitled and integrated members 
of the nation, minorities have been confronted with hostility, social closure, and inward-looking nationalism. Such patterns have been intensified in the context of global terror, catalyzed in the attacks on New York, Bali, London, Madrid, and elsewhere. Being estranged and Othered, certain members of minority groups have retreated into their own glocalized reimagined parallel societies, invoking strands of ethnocultural, linguistic, and religious tradition in order to reify their existences and thereby construct their own ontological security.

Both majorities and minorities have sought refuge in the idealized and distantiated cartography of metropolis and hinterland, anachronistically invoked from the era of navigation and imperial conquest. Indeed, the very construction of majorities as fundamentally unilingual, Caucasian, and possessing what Anderson (1983, page 15) refers to as "a broad horizontal comradeship" is itself illustrative of the bid to assert a fixed social identity in a field of multiple minorities and overlapping place-making projects and practices. This process of sociopsychological place making becomes manifest in 'securitization' strategies in which both structures and collective agency contribute to patterns of (de)securitization.

The Mohammed cartoons controversy, for example, remains vital to discourses of securitization among majorities and Muslim minorities five years after the original publication. This becomes evident by looking at the case of Tahawar Hussain Rana. Rana is a former Pakistani cadet and medical student, with Canadian citizenship of convenience, operating an immigration business and an abattoir in Chicago, USA (Freeze and Ha, 2009). Rana was recently arrested for plotting with David Headley (a Muslim known as Daood Gilani until his name change in 2006) to kill two Danish journalists associated with the Mohammed cartoons publications. The postcolonial referents associated with the case exemplify the deep intertextual ironies and complexities that undermine ontological security among majorities and minorities alike as they engage in a complex of glocalized practices. Rana's immigration business is called First World Immigration Services, while his terrorist operation with David Headley is labeled Mickey Mouse; Rana is a Canadian with scarcely any contact with his country of citizenship; Headley's powerful association with his Pakistani and Muslim identity is revealed in his decision to conceal his aims under a Christian and Western name of convenience; Tahawa Rana is known as Dr Rana in Chicago, drives a Mercedes, and ostentatiously shows off his wealth; Rana and Headley met on a Yahoo discussion website (did they get the Swiftian irony?); and Headley got a visa to visit Denmark under the pretence of wanting to open a branch of First World Immigration Services in Copenhagen. Although Rana and Headley are under arrest for suspected terrorism, the sociospatial relations of their existence, their sense of territory, place, scale, and network are typical of late modern Muslim minorities in the diaspora (Jessop et al, 2008).

The ambiguity of citizenship, identity, and residence associated with Rana is uncomfortably dissonant for majorities and minorities alike. The example of Rana serves to illustrate how assertions of fixed identity become increasingly difficult to uphold, although not necessarily less desirable, in a postcolonial context where space and place are being reconfigured and reasserted. It also points to the insecurities involved in the erosion of clear boundaries and a stable world where identities are known once and for all. As McLuhan so vividly describes it in the introduction to his War and Peace in a Global Village (2001, page 1): "Globes make my head spin. By the time I have located the place, they have changed the boundaries." That this quotation was found as graffiti on a New Delhi toilet wall by one of the authors one year after its original publication only serves to propel a further posthumous spin for McLuhan. 


\section{Regimes of citizenship and multiculturalism in Denmark, Sweden, and Canada}

In the era of decolonization, following the Second World War, European regimes of citizenship and denizenship were established to assimilate new immigrants from the former colonies. A range of entitlements was established, from full and equal (if only 'formal') citizenship to limited guest-worker status. Irrespective of their former status, new immigrants have remained culturally malintegrated throughout Europe and have remained outsiders to the European nationhoods, even when they have made successful claims as citizens of European states.

The 'new nationalism' (Kaldor, 2001) emerging in Europe over the past decade in particular is no longer centered on other nation-states but is increasingly concerned with the enemy within. The definition of the host community becomes crucial as populations may fear changes in their ethnic, religious, or cultural composition, while their governments may fear an increase in xenophobia and populist, antiimmigrant political parties. As Sheehan (2005, page 95) has noted: "European politicians in the early 1990s allowed migration to come to be seen as an issue that could threaten domestic social and political cohesion, and subsequent political developments such as the Gulf wars and Al-Qaida terrorist attacks made it comparatively easy to manipulate sentiments and securitize the migration issue in a negative manner." Muslims have been particularly targeted as being invaders with alien cultures, worshipping other gods and threatening the majority community's ways of life. In the face of such perceptions, and in line with a discourse on terror, European governments have opted for restrictions on migration and for particular measures of surveillance of Muslim communities.

\section{Denmark}

As with the French citizenship regime of laïcité, the Danish model has been one of substantial assimilation, grounded in the expectation that new immigrants who aspire to citizenship will adopt the Danish language, civic values, and Danish culture. The Danish nation is defined as an ethnic community whose cultural survival is guaranteed by the state. This is achieved through the assimilation of immigrants into Danish cultural values. "The concept of cultural homogeneity is thus the most definitional element of the Danish nation" (Holm, 2006, page 4) and has constituted the basis for cultural and institutional racism aimed towards the Muslim community. The growing concern with issues of immigration and settlement has seen a tightening of Danish immigration and refugee regulations since the early 1990s (Valentine et al, 2009, pages 242 -243). The liberal-conservative government that came to power in the 2001 election, with support from the extreme right Danish People's Party, successfully integrated such anti-Muslim notions into a 'fear of immigration' platform. It was no coincidence that Jyllandsposten, a Danish newspaper, decided to publish the caricatures, as immigrants, culture, and religion were integral to the Danish debate (Hedetoft, 2003; Hervik, 2002; Larsen and Seidenfaden, 2006; Mouritsen, 2005). Although not explicitly stated, many of these tough new policies on citizenship and immigration have been directed against Muslim minorities (Holm, 2006; Rytter and Hervik, 2004).

The 'new nationalism', grounded in racist discourses and securitization against the perceived threat of Islam, became culturally and institutionally manifest in the current Danish government and among segments of the Danish population. Such was evident in the government's response to the publication of twelve caricatures of the prophet Mohammed in Jyllandsposten in September 2005. When critics argued that Denmark needed to downplay the cartoon crisis in foreign policy, the Prime Minister immediately rejected that plea, asserting: "Denmark will not become an introvert country. We will maintain our key values both in Denmark and abroad" (Fogh Rasmussen, Politiken 11 February 2006). This response echoes previous Danish Prime Minister Poul Nyrup 
Rasmussen who called a meeting with representative immigrant organizations shortly after the $9 / 11$ attacks. In this meeting he demanded that the participants pledge allegiance to the Danish Constitution and that they should "let their women marry who they want, respect the ideals of democracy and not put the Koran above the Constitution" (Politiken 28 September 2001). As Schmidt (2004) has noted, the demand that women should be able to marry 'who they want' was implicitly connected to the terrorist attacks in the US, although the attacks had no direct relation to gender relationships. Rasmussen was in fact stitching together a glocalized narrative in which Danish security and oriental cultures met through the articulation of the (veiled and benighted) woman. In Nyrup Rasmussen's terminology Muslims were also implicitly regarded as disloyal to democracy because many Muslims claimed that religion should play a role in public life and that Islamic principles should not be secondary to secular legislation (Schmidt, 2004). This official viewpoint was premised on the twin conceits that Christianity is entirely absent from public discourse and practice in Denmark and that Islam as a religion is somehow less rational than either Danish secularism or other religions. As Mouritsen (2005, page 76) argues:

"The Lutheran heritage remains important as facilitating the presentation of Danes as old Christian people. But religion is particularly important in terms of the contrast between Islam as an overly serious un-modern religion, which denotes on the one hand authority and inequality and on the other hand 'modern' individualism and secularism...."

Globalization and the 'war on terror' have also affected the securitization of religion among Muslim minority groups living in Denmark. Initially, the protests in Denmark following the publications of the cartoons on 14 October 2005 drew only some 3500 protesters, who peacefully demonstrated in Copenhagen (Larsen and Seidenfaden, 2006). The reason they later became globalized was partly due to the existence of Islamic entrepreneurs of identity, who played off the reactions of the Danish state, relaying the incident into Egypt, Saudi Arabia, and beyond. The publications constituted an ideal platform for promoting narratives of a worldwide Islamic resurrection.

\section{Sweden}

Both Denmark and Sweden, along with other European countries, have experienced a dramatic shift from predominantly economic migration to the contemporary migration of refugees. Compared with European colonial societies, however, Denmark and Sweden experienced large-scale migration at a relatively late stage. Through the 1980s and the 1990s Sweden sustained a very open migration policy, which resulted in a high level of immigrants in relation to the total population. This policy, which took shape in the 1970s, was grounded in an official multiculturalism whose ideology set the parameters for subsequent public activities. Swedish immigrants were not only encouraged to keep their cultures, but the state actively supported minorities' cultural heritages in terms of home language programs, immigrant organizations, and support for vernacular newspapers and books. With the new liberal-conservative government that came into office in 2006, these policies have increasingly come under question, but a social democratic political hegemony (Alsmark, 2007), characterized by egalitarian notions of welfare, equality, and justice, still continues to dominate much Swedish political thought. In this system migrants have been provided with full formal access to the welfare system, and both Denmark and Sweden are two out of seventeen European states that provide voting rights (denizenship) at the local and regional levels to third-country nationals after three years in residence (Groenendijk, 2007). 
However, as Scuzzarello (2010) notes in a recent doctoral dissertation, the so-called 'Swedish model' of immigration and integration is changing. There has been a tendency to emphasize socioeconomic integration at the cost of multiculturalism (Scuzzarello, 2010; see also Geddes, 2003), and emphasis has been placed on individual rights, self-sufficiency, and self-support as positive indicators of successful integration. While Swedish policy in the 1990s promoted multiculturalism and established an Integration Board, the center-right government that came to power in 2006 closed it down, thus strengthening the competitive, individualistic approach to immigrant policies.

In terms of political power, migrant organizations have not been very successful in Sweden, and it should be noted that ethnic minorities are much better represented in Danish local politics than they are in Sweden (Togeby, 2005). In addition, it is clear that the Swedish multiculturalist model has encountered a number of problems in terms of majority acceptance of Islam and Muslims. Two consecutive Swedish reports published in 2005 and 2006 (Integrationsverkets Rapportserie, 2005; SOU, 2006, page 79 [State Official Report]) show how Islam and Muslims are far from being accepted as a natural feature of a multicultural Sweden. The data used in these analyses come from the Integration Barometer, which is a recurrent questionnairebased national survey carried out by the Swedish Integration Board. These reports show how Muslims are viewed as a threat and how Islamophobia can be discerned in Swedish school books, in the media, and on the Web.

At the same time it is important to point out that there have been stronger tendencies in Danish mainstream society to protect an essentialist colonial notion of 'Danish' culture and traditions and to lament the loss of a mythic past of ethnoreligious solidity. In comparison with Denmark, Sweden has had less of a homogenous idea of the nation-state, which seems to have made it somewhat easier for migrants to integrate (Alsmark, 2007) and less necessary for religion and other identity anchors to act as securitizers. The fact that there have not been any significant public demands from Muslim and other religious or cultural minorities to insist on their own institutional structures in terms of separate laws and parallel political institutions provides some evidence of this. Hence it appears that, despite considerable tension and structural marginalization of migrants in general and Muslims in particular, Swedish multiculturalism has been able to diffuse stark polarization between majority and minority populations, and religious tension has often been desecuritized. Whether this will continue to be the case is, however, not self-evident, and significant differences remain between the Swedish and the Canadian case as discussed below.

\section{Canada}

Despite the starkness and the phobia of the 'wake-up call' discourses of securitization, evolving political cultures in Canada, and the organizations and institutions that have arisen from them, have tended to promote a more muted politics of balance, and Canadians have so far resisted calls to undertake radical change. The power of such political cultural origins has not been substantially affected by globalization, 9/11, or the politics of community isolation or the resort to essentialisms and fundamentalisms. Wiseman's (2007, page 268) attempt to capture Canadian political culture is only the latest of many expressions of the moderate politics of stumbling along, an orientation close to Adorno et al's (1950, pages 461-464) anti-authoritarian "tolerance of ambiguity". The political basis of such accommodation is grounded in a sustained historical tension between liberal individualism and communitarianism throughout Canadian history, in which no single term has been able to achieve ascendancy. Of the many public policy positions to reflect this sense of balance between individualism and communitarianism, 
Canadian multiculturalism is of greatest relevance to how the challenges of ethnoreligious diversity have been addressed. Balancing core individual rights grounded in the liberal tradition with a communitarian commitment to certain rights associated with cultural distinctiveness, Canadian multiculturalism affirms collective aspirations to the extent that substantial groups of citizens continue to demand them but also to the limit that the realization of such aspirations does not inhibit the full and free expression of individual citizenship rights among those claimed as members of designated communities. Thus, communities emerge and are recognized within the Canadian polity, but the groups that claim to speak on their behalf are tentatively welcomed to the extent that their claims to representativeness continue to be validated. Rhetorically, Canadian multiculturalism is premised on the egalitarian claim that all Canadians are refugees and immigrants. Such a bland statement of equality, however, glosses over the critical point that Canada's modern history is that of a European white-settler colony, with all the consequences and reverberations of that mode of historical emergence. Canada's history is profoundly underwritten with practices of racist exclusion, ethnic discrimination, attempts at forced assimilation, and social closure. In this context, the contemporary possibilities for multiculturalism seem restricted and perhaps doomed. The fact that they have not been is due to two important countervailing historical realities. The first is that as an outpost at the margins of European empires, Canada practiced forms of internal colonialism, that, though oppressive, did not constitute Canada itself as an imperial power. It remained on the peripheries, a rich and privileged dependency. An important by-product of this lack of an imperialist past is that, once Canada abandoned its overtly ethnocentric and racist immigration policies in the 1960s and 1970s, it implemented a universalistic and highly selective model of legislated immigration control, grounded in a points system. Thus, multiculturalism in Canada has lacked any direct association with the institutionalized guilt and the deep complexities of postcolonialism associated with many European states. The second historical reality is that, through a complex series of accords and accommodations, no dominant way of life came to achieve cultural hegemony. Thus, a sense of openness and balance has been rendered possible in Canada by the characteristics of its evolving political cultures. The absence of totalizing grand narratives of nationhood has led major public intellectuals in Canada, notably Gwyn (1997) and Saul (2001), to refer to Canada as the first postmodern state long before the postmodern itself had been theorized.

Despite the ongoing challenges, and to some extent because of them, a broad range of empirical evidence, both quantitative and qualitative finds widespread support for the principles and Canadian practices of multiculturalism among the Canadian public, including Muslim minorities. A number of representative samples of Canadian Muslims and non-Muslims have revealed firm and widespread commitment toward multiculturalism among substantial majorities (Adams, 2007; Canadian Islamic Congress, 2003; Khour, 2002; Valpy, 2004). Triadafilopoulos (2006) argues that multiculturalism is of central importance to the life-chances of all Canadians, including Muslims. Not only is it institutionally entrenched and culturally legitimated, but there is powerful evidence that Muslim immigrants value their citizenship rights within the Canadian state. He says: "Canada has succeeded in integrating immigrants and non-immigrants into a tolerant public culture that combines respect for cultural differences with robust levels of national belonging" (Triadafilopoulos, 2006, page 9). 


\section{Regimes of citizenship and multiculturalism compared}

The Danish regime of citizenship requires Muslims to adopt and adapt to a Danish civic identity and enforces assimilation. Such a regime leaves many Muslims experiencing their citizenship as outsiders and aliens, "feeling vulnerable in the face of narrow definitions of Danish nationhood predicated on secularism and whiteness" (Valentine et al, 2009, page 246). In contrast, Swedish multiculturalism (despite its deficiencies) tends to allow for the viability of Muslim communities, networks, and practices, permitting what Valentine et al refer to as the "freedom to define their own narratives of identity" (2009, page 246; see also Phillips, 2006, page 35; Staeheli et al, 2009, page 638). The Canadian variant of multiculturalism encourages both Muslim community development and integration into a network of pan-Canadian civic opportunities for citizenship. In the Danish context those Muslims who are not willing or able to assimilate constitute unwelcome parallel communities that coexist uncomfortably with the regime and the dominant culture. In the Swedish instance, as discussed below, multicultural communities identify with their cultural spaces in the Muslim enclaves but experience their citizenship more broadly through the Muslim diaspora globally. By way of contrast, Muslim minorities in Canada are integrated into a more unified civic nationality. In this regard Muslims in Canada are in "the metaphorical spaces of the public realm" (Staeheli et al, 2009, page 646). The valence of their glocalized existences is shifted strongly toward the national political community relative to their peers in Sweden and especially Denmark.

\section{The political psychology of (de)securitization in action: place-making strategies in Denmark, Sweden, and Canada}

In increasingly multicultural societies, the search for security refers to the ontological anchoring engaged in by both majority and minority communities in order to cope with a range of discursive and structural threats to identity and meaning (Bauman, 1998; Dupuis and Thorns, 1998; Giddens, 1991, pages $38-39$ ). Stated in simple terms, ontological security is a security of being, a sense of confidence and trust that the world is what it appears to be. For Buzan et al (1998) societal insecurity exists when communities define a series of events or an issue as a threat to their survival as a community, be it national, religious, ethnic, or racial. These perceived or real threats may prompt communities to seek sociocultural and religious refuge in a series of 'born again' adoptions of religious, national, or ethnoracial signifiers in order to reestablish meaning and confidence. Majority political societies become more rigid, closed, and authoritarian, while parallel societies among minorities are constructed to foster an equally essentialist political psychology of community cohesion through isolation and retreat.

Culturally, the established orders of religion, community, and family are everywhere in question in response to rapid modernization, global migration, and cultural diffusion, prompting equally strong reactionary countermovements. Ideologically, the liberal enlightenment and its insistence on truth and reason no longer occupy the center stage, and the late modern ideological world is increasingly skeptical of grand narratives. The war on terror has played into the tension created by such processes by simplifying the issues at stake and portraying values as constant, essential, and in need of preservation or eradication. Conditioned by existential panic, discourses on 'civilizational wars', the 'West against the rest', 'fundamentalism', and 'islamophobia' have increased cultural racism in many Western societies at the same time as many minority populations, in particular Muslims, have felt targeted (Modood, 2005). In comparison with past wars concerned with power and territory, the new enemies are seen as being driven by dogmatic belief rather than power gains. 
For Giddens (1991, pages 51 - 53) to be ontologically secure and to avoid existential anxiety is to provide answers to fundamental existential questions. Religion, like nationalism, supplies existential answers to individuals' quests for security by supplying a consistent structure, thereby distilling order from the chaos and uncertainty in the world. In so doing, religion, like nationalism, provides answers to questions concerning existence, self and other, good and evil, and the meaning of life. In providing answers to these questions, religions privilege partial truths, implying an automatic exclusion of those who do not adhere to such truths. The fact that God has set the rules and made them difficult to contest absolves the individual psychologically from the responsibility of having to choose (Juergensmeyer, 2000; Kinnvall, 2006; Mol, 1976). Religion, especially in its monotheistic form, thus provides a foundation for the creation of intolerance against those who do not share core beliefs. Othering becomes, in other words, a fundamental part of the closing of religious boundaries and borders.

The process of constructing religious beliefs as the singular truth is one of ideological work undertaken by religious entrepreneurs of meaning (Laustsen and Waever, 2003). In response to globalization, consumerism, and the spread of Western ideas and practices, religious leaders rail against modern society's lack of morality, loss of ethical values, increased corruption, and so on, arguing that the only answer to the current decay is a return to traditional values and religious norms. Valentine, Sporton, and Nielson's research on Somalis in the UK and Denmark stresses the importance of a Muslim identity and illustrates how "their faith provides an important anchor within their broader experience of dislocation" (Valentine et al, 2009, page 239). Clear boundaries around one's own religion and attacks against other religious interpretations become defensible through the conviction that the sacred struggle is not only a thing of the past but of the present and the future (Juergensmeyer, 2000).

Much has been written about the extent to which nationalism and issues of nationhood provide essentialist notions of bounded communities. Mary Caputi (1996) offers a psychoanalytic reading of national identity in which she explains the deep socialization to a given culture as "a sense of being at home, of being known by others" (page 689). The ontogenetic development of the healthy person is grounded in the capacity to link a core developing personal identity to the social identity of what is known and familiar. The psychodynamic basis of home and community is therefore the process of differentiation and separation that constitutes the very emergence of the human subject. As noted by Reicher and Hopkins (2001, page 51), "[I]f national mobilization depends upon national identity, then establishing identity depends upon embedding it within an essentializing historical narrative." Many of the symbols and tropes of the nation are also invoked in the social construction of religion. As with 19th-century romantic and ethnic nationalism, much of the power of religion resides in its confrontation with Enlightenment principles of rationalism, universalism, secularism, and materialism (Haynes, 1999). As with national consciousness, an assertive religious identity varies in its spatial perception (Haynes, 1997). In the present conjuncture powerfully territorialized nationalisms are encountering radically global and deterritorialized senses of religious belonging. Through its persistent confrontation with modernity, religion has increasingly come to be seen as a distinct 'entity' that is clearly distinguishable from less religious existential spheres (Kinnvall, 2004). As a clearly defined body, it becomes a stabilizing anchor in an otherwise chaotic and changing world, linking past, present, and future action.

Both majority and minority entrepreneurs of identity in Europe are engaged in ideological struggles to win hearts and minds to their securitized national and religious projects (Kepel, 2004, page 249). A number of political/religious leaders would like 
young Muslims to develop a more rigid Islamic identity, rejecting cultural integration and embracing cultural separatism. 'Islamophobia' has often been used by these traditionalists as a resource to define and strengthen Islamic identity - to 're-imagine the Ummah' (Kahani-Hopkins and Hopkins, 2002; Mandaville, 2001) among Muslim diasporic communities. At the same time, expressing anti-Muslim sentiments has almost become a legitimate exercise among parts of the majority communities (Modood, 2005). In this sense, Muslims are featured as invaders, even in societies such as Scandinavia that are marked by an absence of any historical encounter with Muslims. As Bjørgo (1997) has noted, some Norwegian and Danish right-wing discourses have substituted classical anti-Semitic conspiracy theories with anti-Islamic ones. In such discourses Muslim migrants are viewed as part of a coordinated plan to conquer Europe. Responses to $9 / 11$ and the following attacks have also increased a general feeling among Muslims that they are guilty by association even when being separated in both time and space from the actual attacks. Hence, they have often been forced to either condemn actions they had nothing to do with or to explain the true (peaceful) nature of Islam (Larsson, 2005, page 34). They cannot, in other words, separate themselves, their group identity, from the attacks.

Most European countries have also seen an upsurge in populist antiimmigrant parties who encourage the myth that the immigrants, especially Muslims, are taking over 'our' national soil and heritage (eg Le Pen in France, Haider in Austria, Vlams Bloc in Belgium, and the Danish People's Party in Denmark). Responding to such tendencies, the state has institutionalized harder legislation and migration controls to defuse perceived threats to identity and to prevent the spread of xenophobic politics. Some Muslims in Europe have increasingly come to interpret this Eurocentric 'we' as being about threats to their religious identity, at times insisting upon their own system of law, order, and societal security. Among right-wing parties racist views are often combined with more general antiglobal discourses as is the case for the Swedish far-right party Sverigedemokraterna's (Sweden Democrats), for whom immigration, the European Union, US imperialism, and economic globalization are viewed as threats to Swedish culture and 'Swedishness' (Sverigedemokraterna, 2010). There exist some major differences between Sweden and other European societies in terms of real power of right-wing racist parties, however. In Sweden, far-right parties have, so far, been effectively marginalized, while in Denmark and Norway they have gained considerable voter support (Kinnvall and Nesbitt-Larking, 2010; Rydgren, 2005).

Many Muslims in the diaspora find that their religion assumes new significance, and/or discover that its symbolic connotations have somehow shifted (Mandaville, 2001; Schmidt, 2004). When the security anchor of home is lost, new moorings - or a new 'home' - for ontological security are searched for. Homesteading as a strategy means making and shaping a political space for oneself in order to go beyond and surpass the life of contradictions and anxieties of homelessness (Sylvester, 1994). For many migrants and minority communities, homesteading works as a bordering practice and becomes a way to counter homelessness and return intimacy and security to their everyday lives.

Homesteading often involves what Castles and Davidson (2000) have referred to as 'place-making' processes. These can be seen as spatial extensions of homebuilding. Place making means creating an area, a neighborhood, that visibly transforms the previous landscape into one that reflects the tastes and values of a certain community. The use of signs on shops, restaurants, minority markets, and other signifiers, delineates the community's boundaries. The place-making construction of localized communities is defensive, a bid to secure a familiar public space with symbolic attachments to the homeland. Thus, the local is constituted from and in vibrant interaction with the global. 
Majority populations, in responding to real or perceived increases in migration, are also engaged in homesteading. The whole notion of home is built upon the idea, or the discourse, of the nation-state, bringing with it an emotional attachment to those on the inside and an exclusion of those on the outside. Hence, place making - in terms of reinterpreting tradition, religion, and culture - is as likely among the majority population as it is among the minorities.

Amplifying the alienation of the secular state and civil society, minority religious leaders assert their own religious doctrine through their criticism of structured marginalization and the emptiness of Western culture. Such righteousness sanctions the construction of parallel societies, a withdrawal from majority culture, and therefore an ever-essentialized portrayal of in-group and out-group characteristics and motives. In extreme cases, such conditions may lead to the sanctioning of violence. As Juergensmeyer (2000, pages $383-384$ ) has noted, religion provides a metamorality, which can disregard regular moral restrictions on the dehumanizing of others and even killing. Like the nation, religion is not 'just there' in any objective sense of the term but must be rediscovered, reinvented, and rebordered every time it is called upon as an answer to ontological insecurity. The major world religions may have fixed texts, "but they do not have fixed beliefs, only fixed interpretations of those beliefs" (Thomas, 1999, page 37). The more essentialist such interpretations become in establishing links between past historic events, the more successful they will be in terms of inclusiveness and exclusiveness - in creating boundaries between self and Other. ${ }^{(1)}$

As we stated earlier, the specific legacy of empire and colonization in conjunction with its citizenship regimes has conditioned a deep and mutual multiculturalism in Canada. Within the context of such a political society, a politics of engagement is possible, and cosmopolitical and dialogical practices are able to counter trends toward essentialism and retreatism. A cosmopolitical approach is sustained through a radical problematization of self and Other in the ongoing reproduction of individual consciousnesses, discourses, and social relations. Its sociopolitical prerequisites include the pluralistic politics of engagement and mutual regard within the context of critical postcolonial multiculturalisms. Cosmopolitics eschew both extremes of the bland universal space of liberal cosmopolitanism (a cartography of imperialism and colonization) on the one hand and the attempted enclosedness of communitarian space (an essentialist mapping of fixed and immutable cultures) on the other. Traditional cosmopolitanism relies on a discourse of individual rights that is grounded in ideologies of possessive individualism and the nation-state form-while communitarianism is based on a discourse of social rights that is often expressed in exclusive localism. Both run the risk of substituting ethics for politics. A cosmopolitical approach is in line with critical multiculturalism, which is both aware of its own history and fully open to transformation, and proceeds from an understanding of self as dialogical (Calhoun, 2003). Drawing on Bakhtin (1979/1986), Marková (2003) formulates an ontology that places dialogicality at the center. Dialogicality, according to Markova, refers to the capacity of the human mind to conceive, create, and communicate social realities, implying that the dialogical relation is also an existential relation. Taking dialogicality seriously suggests that our social-psychological questions must be posed differently than those asked in nondialogical approaches. They should not involve individuals and groups as separate entities. Instead, they should involve varieties of Ego-Alter relations, which cannot be anything but communicative. Thus, when investigating minorities, for example, they should be viewed as mutually interdependent with majorities.

(1) The attack on the Twin Towers, for instance, can be seen as an attack on a building symbolizing the antithesis of the values of Islam (seen in the eyes of the attackers), personifying the moral decay of the West with the US as its main representative. 


\section{Denmark}

Our interviews with young Danish Muslims show how structural exclusion and psychological vulnerability have affected many of them in their search for an identity. Islamic organizations or movements have been able to securitize religion by emphasising cross-national Muslim belonging, which has appealed to many young Muslims. In this sense young Muslims tend to be more likely than their parents to adopt the categorical classification of the majority community to see themselves first and foremost as Muslims (Lassen and Østergaard, 2006; Schmidt, 2004). Some of these young Muslims distance themselves from their parents' homeland traditions in favour of a 'pure' and 'authentic' Islam - as expressed by the now deceased Sheik Abu Laban and other fundamentalist leaders.

Hence for many of these young people, often young men, an abstract ummah-a global Muslim community - reflects their beliefs in a more expansive Islam. The emphasis on a global ummah opens up for a hardening of the boundaries around both a Danish identity and an anti-Western global identity, often referred to as 'Western-phobia' (see Larsson, 2006). The identification with a global ummah tends to challenge the self-perception of Western liberal democracies and the ideas of a secular and essential national identity by providing an alternative approach. Schmidt's (2004) interviews with young Muslims in Denmark and Sweden confirm how the migration process itself has added to this 'purification' of Islam, while Mandaville (2001) shows how local Muslim student associations use the Internet as an effective tool for the establishment of a transnational Islamic discourse - a reimagined ummah. Transnational communication therefore opens up local possibilities for emotionally identifying with global discourses and movements. The global community represents a 'good enough' locus of religious anchoring in which place making is made possible through the minimalist requirement of 'a room (or cubicle) of one's own'. The Mohammed cartoons would never have received the same amount of attention without the new information and communications technologies. In response to perceived structural and psychological exclusion among many young diasporic Muslims, global narratives have been integrated into local institutional and cultural practices.

The Mohammed cartoon crisis became globalized due to some strategic and tactical moves by certain members of the Danish Muslim community. The crisis was further aggravated by the decision on 19 October 2005 of then Danish Prime Minister, Anders Fogh Rasmussen, not to meet with ambassadors from eleven Islamic countries to discuss the cartoons. This meeting had been initiated by a Danish imam, Ahmed Abu Laban, one of those involved in the circulation of the caricatures. By the middle of November 2005, Abu Laban had made arrangements on behalf of the Organization of Islamic Faith to send a delegation to publicize the cartoon issue. The delegation visited Cairo, Damascus, and Beirut in December to present the original twelve cartoons along with three others that had not been originally published. There were also several letters by Abu Laban concerning the increasingly hostile climate in Denmark towards Islam (Politiken 2005). The narratives around these pictures became severely distorted in the process of translation. One of the pictures, a photograph of a man with a pig's ear and snout [later identified as an old Associated Press picture from a French 'pig-squealing' contest (Reynolds, 2006)], was included only as an example of the hate letters that had been circulated in the process (Larsen and Seidenfaden, 2006). However, it was assumed by many to have been part of the original set.

Hence, it is not enough to say that it was the offensive nature of the cartoons that created the outcry throughout the world. More important is how the diffusion of the cartoons played into a number of local events, such as the electoral successes of 
religious parties in Egypt, Iraq, and the Palestinian territories together with increasing confrontation over Iran's nuclear ambitions. Adel Hamouda, editor of the liberal Cairo-based weekly, had actually published the cartoons in October 2005. He pointed out that: " $[\mathrm{N}]$ o one noticed. Those who saw the cartoons did not react, and those who reacted are those who did not see them" (quoted in Newsweek 2006; see also The Guardian 2006). The subsequent outcry can partly be traced to the Danish delegation's visit to the Middle East and the televised press conference broadcast throughout the Arab world in which Danish Prime Minister Rasmussen spoke of President Bush's support for Denmark (Larsen and Seidenfaden, 2006, page 170). However, the reaction should also be viewed in relation to how the election results emboldened regimes and movements in the region that were able to channel diffuse discontents into anti-Western hostility.

In a narrative sense, we must understand the emergence of 'new nationalism' in Europe as a shift in rhetoric from 'race' to 'culture', where racist discrimination is increasingly justified by means of exclusive cultural difference. The emphasis in the media and among policy makers and many ordinary Danes is increasingly that immigrants do not 'naturally' belong to Denmark: "Residents are 'We', the 'Danes', 'the indigenous Danes', those who were here 'to begin with' or those who belong 'naturally' to the territory and imagine themselves as a homogenous cultural community" (Hervik, 2004, page 258) The narrative dimensions of colonization, globalization, and the war on terror have been especially instructive for the securitization of Danishness, as more Danes have become preoccupied with securitizing their home and nationparticularly in opposition to a vilified Muslim Other.

For their part, Danish Muslims have been largely denied the possibilities of dialogical engagement and a cosmoplitical entrance into the broader Danish political society. Under circumstances such as the Mohammed cartoon crisis, phenomenologies of territory and place have found Danish Muslims retreating from shared public space and entering the virtual ummah or the basement mosque: a politics of grandiose communities forged in small rooms. Place-making strategies have centered on both the establishment of beleaguered Danish Muslim enclaves and the hope for returns to the distant homeland wherever possible.

\section{Sweden}

As in Denmark, it is clear that anti-Muslim sentiments in Sweden increased following 11 September. A report published in 2005 by the Swedish Department of Integration showed that $60 \%$ of respondents agreed with the statement that Islam cannot coexist with basic 'Swedish values', and only four out of ten believed that 'Swedish Muslims are like Swedes in general'. Swedish mosques in migrant cities like Malmö and Trollhättan have also been attacked on several occasions by anti-Muslim groups. The effects of such Islamophobia and racism are most visible in the Swedish job market. Failed integration has a number of consequences, documented in Sweden and elsewhere, such as increased spatial segregation, economic marginalization, illegal economic activities, the formation of gangs, and a culture of violence. In Sweden ethnic harassment of and discrimination against job-seekers (based on ethnicity, skin color, religious affiliation) are common features of the labor market, as they are elsewhere in the EU (Larsson, 2006). In those cases where integration policies fail it is likely that homeland cultural practices become important securitizing tools, thus creating and/or strengthening separate identities and spaces. The emergence of parallel societies and homesteading practices in both Sweden and Denmark must be viewed as a combination of housing policies, restrictions in job-market access, and stereotypical categorizations of immigrants by segments of the majority society. These enclaves always generate entrepreneurs 
of identity who attempt to strengthen their positions within their communities through further isolating them. Inadequate integration of migrants, especially Muslim migrants, has also resulted in more essentialist, anti-Muslim, securitizing practices among those of the majority population who have retreated to their own suburban 'safe havens'.

In comparison with Denmark, however, where discourses on migrants and Muslims have been significantly more polarized and harsher, Swedish multiculturalism remains less of a perceived threat among both politicians and the general public. This became evident in the Swedish equivalent to the Danish cartoon crisis, the so-called 'Mohammed as a dog debate'. In July 2007 the Swedish artist Lars Vilks drew a picture of the Prophet Mohammed as a so-called 'roundabout' dog [a rather peculiar phenomenon of (mostly) wooden dogs starting to appear in the middle of roundabouts in 2007 all over Sweden]. The picture was intended for an art exhibition outside the city of Karlstad, but the event was cancelled after pressure had been put on the organizers. There were also concerns about the offensive nature of the picture. Media soon picked up on the issue, comparing it to the Mohammed crisis in Denmark, and for a few months it created an intense media debate. Finally, Vilks's drawing was published in a small local newspaper (Nerikes Allehanda), and within a month the President of Iran had publicly condemned the publication. This was followed by threats against Swedish companies, against Vilks himself_-including a reward from (allegedly) al-Qaeda for having Vilks killed - and the burning of a puppet of the Swedish Prime Minister Fredrik Reinfeldt (Brink, 2007a; 2007b; Hansson, 2007).

Compared with the Danish Mohammed cartoon controversy, reactions came a lot faster from both diplomats and representatives of Islamist networks and tensions were soon deescalated-mostly by looking at the Danish experience and then doing the opposite. Hence, Prime Minister Reinfeldt decided to visit the main mosque in Stockholm to discuss the situation. He also received ambassadors from Arabic and Muslim countries and contacted Swedish embassies in these countries to spread the message that "Sweden is a country where Christians and Muslims live side by side" and that "our constitution does not decide what the newspapers should print" (El Mahdi, 2007). Muslim organizations in Sweden also immediately tried to avoid an escalation of the crisis, declaring that this was a local Swedish issue that should be handled peacefully. Even if there were some people within Swedish Muslim organizations who wanted to internationalize their protests, the majority preferred dialogue to boycotts and violent demonstrations. They also offered to cooperate with the Swedish Ministry of Foreign Affairs at an early stage of the crisis. In addition, young Muslims in Sweden had developed a network of 'peace agents' in response to the Danish cartoon crisis in order to better respond to Islamophobia and prejudices and to counter extremism and violence. These young people spoke out against violence as the debate was unfolding in Sweden (El Mahdi, 2007). These developments illustrate the relatively greater cosmopolitical and dialogical elements that undergird Swedish political culture. As is evident in the range of responses to the Mohammed crisis in Sweden, majority actors were prompted to engage their Muslim neighbors in face-to-face dialogical encounters and to imagine the realm of the glocal together.

As an avant-garde artist, Lars Vilks made it his business to provoke. Irrespective of his particular motivations, however, a considerable number of Muslims of diverse origins viewed Vilks's roundabout dog as a deliberate act of defamation against the Muslim religion and an attempt to increase Swedish Muslims' alienation from mainstream society. Even among moderate and secular Swedish Muslims many felt offended by this act. The fact that it failed to escalate as it did in Denmark can be explained by a number of factors. One has to do with the political climate in Denmark, where an openly racist, anti-Muslim party (Danish People's Party) has influenced the securitization 
of political discourse and the cultural institutionalization of such discourse. In Sweden anti-immigrant parties have been relatively marginalized from mainstream politics. The political climate in Denmark has polarized communities, pushing immigrants and Danish nationalists apart - thus feeding securitizing responses from both sides. They literally exist apart from each other and eschew contact. Another factor may have to do with the Danish decision to send troops to Iraq, thus implicating Denmark in President Bush's war on terror. In addition, not much support existed among the majority population in Sweden of Vilks's portrayal of Mohammed as a 'roundabout dog'; it was mainly perceived as an artistic provocation. In contrast, the decision by the Jyllandsposten to publish was, according to Larsen and Seidenfaden (2006), more than a diffuse expression of artistic freedom. It was a defiant assertion of 'freedom of speech' in the face of what the editors had constructed as Islamic backwardness and extremism. Such aggression is the consequence of 'two solitudes', engaged in a dialogue of the deaf, the concussive battering of bland claims-making as opposed to truly speaking to each other and being heard.

\section{Canada}

The 49th Parallel dividing Canada and the USA is said to be the longest undefended boundary in the world, and Canada's borders have been variously described as 'permeable' (Gibbens, 2005; Salter, 2004) and as 'porous' (Ferguson, 2006; Olmedo and Soden, 2005). Among the large nations of the world, Canada has the highest rates of immigration (Canada, 2004). Faced with growing global discourses of securitization and 'moral panics' (Thompson, 1998) over the malevolent intentions of terrorists, Canada has appeared to some to be naively unprepared to confront its enemies. Mark Steyn (2006) and David Harris (2008) are among the more prominent voices to have promoted antiterrorist discourses of securitization and to have claimed that the Canadian government and Canada's 'elites' are in denial regarding the surging tidal waves of global terror. While their voices are dramatic, confrontational, and insistent, the securitizing discourses that they represent have not so far overwhelmed the deeper and more nuanced Canadian political culture of moderation and balance (Nesbitt-Larking, 2007).

The dialogue on individual rights and community respect, on the balances among liberty, equality, and order in an equitable polity are both intersubjective andthrough practices of dialogicality-subjective. Through open and frank dialogue and through critical introspection, the challenges confronted by insults toward religious beliefs and perceptions of blasphemy and apostasy can be addressed without resort to the politics of suppression, group entrenchment, and essentialism. The Canadian response to the dissemination of the Mohammed cartoons is typical of a pattern of responses toward community sensitivity that have emerged over the past decades and are grounded in the broader evolution of Canadian political culture. Prior to the Mohammed cartoon crisis, an earlier global shock took place in 1988 and 1989 with reactions to the release of Salman Rushdie's The Satanic Verses. In a carefully researched analysis of Canadian Muslim reactions toward the impact of the novel, Amir Hussain (2002) establishes both the extent of knowledge, concern, and hurt regarding the novel as well as the determination among Muslims in Canada either to demonstrate peacefully or to assist their fellow Muslims toward a deeper appreciation of the complexities of the novel itself. Hussain concludes that: "On the whole, the Canadian responses were much more muted and peaceful than those in other countries" (2002, page 26).

Reaction to the Mohammed cartoon controversy in Canada in early 2006 was equally muted and moderate and generally succeeded in avoiding violence and prolonged controversy through careful dialogue, a common will to desecuritize, and the statement of balanced public positions on the part of Muslim organizations, politicians, and the 
Canadian media. A statement signed by twenty-one national Muslim organizations in Canada, released on 17 February 2006, read in part: "Canadians have collectively responded to the publication of the offensive caricatures of the Prophet Muhammad in a manner that has strengthened our nation.... Canada's response has been unique and has struck the right balance between freedom of expression, and the legal and moral right of citizens to be protected from publications promoting hate and racism ... as Muslims, and as Canadians, we say to our nation: you have made us proud!" (CAIR-CAN, 2006). Both the Prime Minister and the Foreign Affairs Minister called for greater understanding of Islam and Muslims, while condemning violent actions. Canada's mainstream newspapers followed the lead of a carefully worded and lengthy editorial from The Globe and Mail, explaining why within the context of a strong defense of freedom of expression the newspaper decided not to publish the cartoons. Editor Edward Greenspon pointed out that there was lengthy and fraught discussion among the editorial team on the matter of whether to reproduce the cartoons and that the decision had not been easy. In the end, they came to the conclusion that to publish would be "both gratuitous and unnecessarily provocative, especially given what we knew about how offended Muslims ... felt about the cartoons. It didn't seem to be a matter of publish and be damned, but more like 'damn you' and publish...” (Greenspon, 2006, page A2).

An insignificant number of minor publications in Canada chose to take a stand and to publish the cartoons, most notably the Western Standard. Editor Ezra Levant claimed that other newspapers had refused to publish through fear of an economic backlash and/or violence from angry Muslims (Levant, 2006). Along with Steyn and Harris, Levant represents a distinctive voice in Canada that regards contemporary Islam and Muslims as dangers to freedom and democracy and believes that the most useful approach toward sustaining democracy in Canada is uncompromisingly aggressive and combative. These views are sufficiently resonant among a minority of others in Canada to have led the town council of Herouxville, Quebec (population 1338), a village with no nonwhite or Muslim immigrants, to pass a resolution banning (among other matters) the stoning of women, female genital cutting, and burning women alive. The passage of these measures attracted international attention and condemnation from a range of ethnoreligious organizations. However, the prevailing Canadian viewpoint is best expressed in the words of Gerard Bouchard and Charles Taylor, authors of the Reasonable Accommodation report, written partially in response to the Herouxville incident, who said: "The way to overcome Islamophobia is to draw closer to Muslims, not to flee them" (2008, page 84). In light of the Mohammed cartoon crisis, key members of majority and minority communities in Canada insisted upon sustaining dialogue and a cosmopolitical approach toward balancing rights, responsibilities, and sensibilities.

\section{Conclusion: desecuritizing religion, promoting dialogicality and cosmopolitics}

The Canadian and to some extent the Swedish example indicate the importance of a cosmopolitical approach toward the desecuritization of religion (Archibugi, 2003; Cheah and Robbins, 1998). Notions of dialogicality and cosmopolitics can be helpful in avoiding the danger of ethnocentrism and of being locked in either the epistemic overpowering of the Other, or in historicism, individualization, and concealment of power structures and practices (Kinnvall and Lindén, 2010). Desecuritizing religion, in particular Islam, hence requires a careful rethinking of how Muslim minority communities are being targeted in discourses on terror and new nationalism in Europe and Canada, as well as in the institutionalization of such discourses in antiterror measures and securitizing activities. Desecuritization is a dissolving of borders and margins, 
of metropole and hinterland, based upon practices in which a plurality of communities and individuals participate in mutual practices of political engagement through encounter and engagement across a range of settings from the local to the global. The dialogical encounters of a cosmopolitical order are frequently agonistic, resisting easy reconciliation, but nonetheless in dialogue. The discourses and narratives that constitute the shifting majority and minority cultures are neither hopelessly remote from each other nor blandly in concert. Far from being essential entities, Balibar reminds us that cultures have "a history, and it is the unending process of translation [through dialogue] that reflects and allows them to transform this history" (2009, page 209). Dialogical encounters permit the determination and maintenance of inhabitable and adequate space in what Sloterdijk refers to as 'hyperpolitics' (Morin, 2009, pages 68-69). Cosmopolitan assimilation (Denmark) and limited multiculturalism that stops short of full engagement in the civic nation (Sweden) promote a neo-Westphalian politics of constructed borders and imagined metropoles and remote peripheries. A cosmopolitical and deeply dialogical multicultural order, such as that which has been emerging in Canada, is capable of reconfiguring space and place through renewed networks of contingent and hybrid belonging.

Acknowledgements. The authors wish to thank Stuart Elden (Durham University), Jeff Hopkins (University of Western Ontario), and two anonymous reviewers for their invaluable guidance in the preparation of this article. One of the authors (Kinnvall) also acknowledges support from the project "Democracy Beyond the Nation State? Transnational Actors and Global Governance", funded by Riksbankens Jubileumsfond.

\section{References}

Adams M, 2007 Unlikely Utopia: The Surprising Triumph of Canadian Pluralism (Viking, Toronto) Adorno T, Frenkel-Brunswik E, Levinson D J, Nevitt Sanford R, 1950 The Authoritarian Personality (Harper and Brothers, New York)

Alsmark G, 2007, "Integrationspolitik på svenska", in Inklusions- och Exklusionsprocesser i Skandinavien Eds G Alsmark, T Kallehave, B Moldenhawer (Makadam, Göteborg) pp $53-98$

Anderson B, 1983 Imagined Communities: Reflections on the Origin and Spread of Nationalism (Verso, London)

Archibugi D (Ed.), 2003 Debating Cosmopolitics (Verso, London)

Bakhtin M, 1979/1986 Speech Genres and Other Late Essays (University of Texas Press, Austin, TX)

Balibar E, 2009, “Europe as borderland” Environment and Planning D: Society and Space 27190 - 215

Bauman Z, 1998 Globalization: The Human Consequences (Polity Press, Cambridge)

Bauman Z, 2001 Community: Seeking Safety in an Insecure World (Polity Press, Cambridge)

Bjørgo T, 1997, “'The invaders', 'the traitors' and 'the resistance movement': the extreme right's conceptualisation of opponents and self in Scandinavia"', in The Politics of Multiculturalism in the New Europe: Racism, Identity and Community Eds T Modood, P Werbner (Zed Books, London) pp $54-72$

Bouchard G, Taylor C, 2008 Building a Future: A Time for Reconciliation: Abridged Report also known as the Reasonable Accommodation Report (Gouvernement du Quebec, Quebec)

Brink, B, 2007a, "Teckningar på Muhammed togs bort” Svenska Dagbladet 21 July

Brink B, 2007b, "Fatwa förbjuder dödshot mot Vilks" Svenska Dagbladet 17 September

Buzan B, Waever O, de Wilde J, 1998 Security: A New Framework for Analysis (Lynne Rienner, Boulder, $\mathrm{CO}$ )

CAIR-CAN, 2006, "National Muslim Coalition issues statement on cartoon controversy", CAIR-CAN press release, 17 February, http://www.caircan.ca/print_itn_more.php? id=2320_0_2_0_M

Calhoun C, 1995 Critical Social Theory (Blackwell, Oxford)

Calhoun C, 2003, "The class consciousness of frequent travellers: towards a critique of actually existing cosmopolitanism", in Debating Cosmopolitics Ed. D Archibugi (Verso, London)

Canada, 2004 Canada's Immigration Program Parliamentary Information and Research Service, Library of Parliament, http://www.parl.gc.ca/information/library/PRBpubs/bp190-e.htm\#20 
Canadian Islamic Congress, 2003, "In the shadow of 9/11: Islamic Congress polls Canadian university students", http://www.carleton.ca/-pryan/CIC.bulletin.030912.cic.txt

Caputi M, 1996, "National identity in contemporary theory" Political Psychology 17 683-694

Castles S, Davidson A, 2000 Citizenship and Migration: Globalization and the Politics of Belonging (Macmillan, Basingstoke, Hants)

Cheah P, Robbins B (Eds), 1998 Cosmopolitics: Thinking and Feeling Beyond the Nation (University of Minnesota Press, Minneapolis, MN)

Dupuis A, Thorns D C, 1998, "Home, home ownership and the search for ontological security" Sociological Review $4624-47$

El Mahdi J, 2007, "Reinfeldt och fredsagenterna parerade Vilks-krisen briljant" Svenska Dagbladet 7 October

Ferguson M, 2006, "Invisible divides: communication and identity in Canada and the U.S." Journal of Communication $4342-57$

Freeze C, Ha T T, 2009, “The 'Mickey Mouse' mastermind: Canadian charged in plot against Danish newspaper" Globe and Mail 28 October, pages A1 - A2

Geddes A, 2003 The Politics of Migration and Immigration in Europe (Sage, London)

Gibbens R, 2005, "Meaning and significance of the Canadian-American border", in Borders and Border Politics in a Globalizing World Eds P Ganster, D E Lorey (Rowman and Littlefield, Lanham, MD) pp $151-168$

Giddens A, 1984 The Constitution of Society (University of California Press, Berkeley, CA)

Giddens A, 1991 Modernity and Self-identity: Self and Society in the Late Modern Age (Polity Press, Cambridge)

Greenspon E, 2006, "Self-censorship versus editing" The Globe and Mail 11 February, page A2

Groenendijk K, 2007, "The long-term residents directive, Denizenship and integration", in Whose Freedom, Security and Justice? EU Immigration and Asylum Law and Policy

Eds A Baldaccini, E Guild, H Toner (Hart Publishing, Oxford) pp 429-450

Gwyn R, 1997 Nationalism Without Walls: The Unbearable Lightness of Being Canadian (McClelland and Stewart, Toronto)

Hall S (Ed.), 1992 Modernity and Its Futures (Polity Press, Cambridge)

Hansson A, 2007, “Öppning för Vilks 'Muhammedhundar'” Svenska Dagbladet 6 October

Harris D B, 2008, "Is Canada losing the balance between liberty and security?", in Immigration Policy and the Terrorist Threat in Canada and the United States Eds A Moens, M Collacott (The Fraser Institute, Vancouver) pp 129 - 159, http://www.thefraserinstitute.org

Haynes J, 1997, "Religion, secularisation and politics: a postmodern conspectus" Third World Quarterly $18705-728$

Haynes J (Ed.), 1999 Religion, Globalization and Political Culture in the Third World (Macmillan, Basingstoke, Hants)

Hedetoft U, 2003 The Global Turn: National Encounters with the World (Aalborg University Press, Aalborg)

Hervik P, 2002, "Mediernes Muslimer: en antropologisk undersøgelse af mediernes daekning af religioner i Danmark" (Naevnet for Etnisk Ligestilling, Copenhagen)

Hervik P, 2004, "The Danish cultural world of unbridgeable differences" Ethnos 69247 - 267

Hervik P, 2006, "The predictable responses to the Danish cartoons" Global Media and Communication $2225-230$

Holm U, 2006, "The Danish ugly ducking and the Mohammed cartoons" DIIS Brief Danish Institute for International Studies, Copenhagen

Hussain A, 2002, "Misunderstandings and hurt: how Canadians joined worldwide Muslim reactions to Salman Rushdie's The Satanic Verses" Journal of the American Academy of Religion 701 - 32

Integrationsverkets Rapportserie, 2005 Rasism och Främlingsfientlighet i Sverige: rapporter och delstudier om rasism och främlingsfientlighet i Sverige 2004 (Integrationsverket, Norrköping)

Jessop B, Brenner N, Jones M, 2008, “Theorizing sociospatial relations” Environment and Planning D: Society and Space $26389-401$

Juergensmeyer M, 2000 Terror in the Mind of God: The Global Rise of Religious Violence (University of California Press, Berkeley, CA)

Kahani-Hopkins V, Hopkins N, 2002, “'Representing' British Muslims: the strategic dimension to identity construction" Ethnic and Racial Studies 25288 - 309

Kaldor M, 2001 New and Old Wars: Organized Violence in a Global Era (Stanford University Press, Stanford, CA)

Kepel G, 2004 The War for Muslim Minds: Islam and the West (Harvard University Press, Cambridge, MA) 
Khouri R G, 2006 Arabs in Canada: Post 9/11 (Canadian Arab Federation, Toronto)

Kinnvall C, 2004, "Globalization and religious nationalism: self, identity, and the search for ontological security" Political Psychology 25741 - 767

Kinnvall C, 2006 Globalization and Religious Nationalism in India: The Search for Ontological Security (Routledge, London)

Kinnvall C, Lindén J, 2010, "Security and dialogical selves: migration, multiculturalism and the challenge of the global" Theory and Psychology forthcoming

Kinnvall C, Nesbitt-Larking P, 2010 The Political Psychology of Globalization: Muslims in the West (Oxford University Press, New York) forthcoming

Larsen R, Seidenfaden T, 2006 Karikaturkrisen: en undersøgelse af baggrund og ansvar (Gyldendal, Copenhagen)

Larsson G, 2005, "The impact of global conflicts on local contexts: Muslims in Sweden after 9/11 the rise of Islamophobia, or new possibilities" Islam and Christian - Muslim Relations 16 29-42

Larsson G, 2006, "Muslims in the EU: Cities Report on Sweden", EU Monitoring and Advocacy Program, Open Society Institute, http://www.soros.org/initiatives/home/articles_publications/ publications/museucities_20080101/museucitiesswe_20080101.pdf

Lassen S, Østergaard K, 2006, "Tvarnationale bevagelser blandt muslimer i Danmark”, in Invandrare och Integration i Danmark och Sverige Eds U Hedetof, B Petersson, L Surfelt (Makadam Förlag, Göteborg) pp $201-238$

Laustsen B C, Waever O, 2003, "In defense on religion: sacred referent objects for securitization", in Religion in International Relations: The Return from Exile Eds F Petito, P Hatzopoulos (Palgrave, Basingstoke, Hants) pp $147-180$

Levant E, 2006, "Media runs scared" Calgary Sun 13 February

McLuhan M, 2001 War and Peace in a Global Village (Gingko Press, Berkeley, CA)

Mandaville P, 2001 Transnational Muslim Politics: Reimagining the Umma (Routledge, London)

Marková I, 2003 Dialogicality and Social Representations: The Dynamics of Mind (Cambridge University Press, New York)

Modood T, 2005 Multiculturalism, Muslims and Citizenship: A European Approach (Routledge, London)

Mol H, 1976 Identity and the Sacred: A Sketch for a New Social-scientific Theory of Religion (Blackwell, Oxford)

Morin M, 2009, "Cohabitating in the globalised world: Peter Sloterdijk's global foams and Bruno Latour's cosmopolitics" Environment and Planning D: Society and Space $2758-72$

Mouritsen P, 2005, "The particular universalism of a Nordic civic nation: common values, state religion and Islam in Danish political culture", in Multiculturalism, Muslims and Citizenship: A European Approach Eds T Modood R, Zapate-Barrero, A Triandafyllidou (Routledge, London) pp $70-95$

Nesbitt-Larking P, 2007, "Canadian Muslims: political discourses in tension” British Journal of Canadian Studies $201-24$

Newsweek 2006, "Pointing the finger", 20 February

Olmeda C, Soden D L, 2005, "Terrorism's role in re-shaping border crossings: 11 September and the US borders" Geopolitics $10741-766$

Phillips D, 2006, "Parallel lives? Challenging discourses of British Muslim self-segregation" Environment and Planning D: Society and Space $2425-40$

Politiken 2005, "Declaration regarding ethnic discrimination in Denmark", 10 December

Reicher S, Hopkins N, 2001 Self and Nation: Categorization, Contestation and Mobilization (Sage, London)

Reynolds P, 2006, "Cartoons: divisions and inconsistencies" BBC News 13 February

Robertson R, 1995, "Glocalization: time - space and homogeneity - heterogeneity", in Global Modernities Eds M Featherstone, S Lash, R Robertson (Sage, London) pp 25-44

Rydgren J, 2005, "Radical right-wing populism in Sweden and Denmark", Working Paper, The Centre for the Study of European Politics and Society, http://hsf.bgu.ac.il/europe/ index.aspx?pgid=pg_127842651505941456

Rytter M, Hervik P, 2004, "Med ägteskab i focus”, in Ägtefällesammenföring i Danmark'. Inquiry 1 volume 6 (Institute for Human Rights, Copenhagen) pp 131 - 160

Salter M B, 2004, "Passports, mobility and security: how smart can the border be?" International Studies Perspectives $571-91$

Saul J R, 2001, "My Canada includes the north" The Globe and Mail 9 March, http://www.theglobeandmail.com/series/lafontaine/stories/COMYTHS5.html 
Schmidt G, 2004, "Islamic identity formation among young Muslims: the case of Denmark, Sweden and the United States" Journal of Muslim Affairs 2431 - 45

Scuzzarello S, 2005, "The West and its discontents", paper presented at the Political Science Association, Lund, October 2005

Scuzzarello S, 2010 Caring Multiculturalism and Local Immigrant Policies: Narrating Integration in Birmingham, Bologna, and Malmö to be defended at Lund University, Lund (forthcoming)

Sheehan M, 2005 International Security: An Analytical Survey (Lynne Rienner, Boulder, CO)

SOU, 2006 Integrationens Svarta Bok: Agenda för jämlikhet och social Sammanhållning 79 (Regeringskansliet, Statens Offentliga Utredning)

Staeheli L A, Mitchell D, Nagel C R, 2009 "Making publics: immigrants, regimes of publicity and entry to "the public" "Environment and Planning D: Society and Space 27 633-648

Steyn M, 2006 "The future belongs to Islam" Macleans Magazine 20 October, http://www.macleans.ca/article.jsp?content=20061023_134898_134898\&source

Sverigedemokraterna, 2010, "Invandringspolitiskt program", http://sverigedemokraterna.se/ vara-asikter/invandringspolitisk-program/

Sylvester C, 1994 Feminist Theory and International Relations in a Postmodern Era (Cambridge University Press, Cambridge)

The Guardian 2006, "Danish paper rejected Jesus cartoons", 6 February

Thomas S, 1999 "Religion and international society", in Religion, Globalization and Political Culture in the Third World Ed. J Haynes (Macmillan, Basingstoke, Hants) pp 28-44

Thompson K, 1998 Moral Panics (Routledge, London)

Togeby L, 2005, "The electoral system and representation of ethnic minorities", paper presented at the Annual Meeting of the American Political Science Association, Washington, DC, 1 September

Triadafilopoulos T, 2006 "A model for Europe? An appraisal of Canadian integration policies", in Politische Steuerung von Integrationsprozessen: Intentionen und Wirkungen (Verlag für Sozialwissenschaften, Wiesbaden) pp $1-16$

Valentine G, Sporton D, Bang Nielson K, 2009 "Identities and belonging: a study of Somali refugee and asylum seekers living in the UK and Denmark" Environment and Planning D: Society and Space $27234-250$

Valpy M, 2004 "Canadians tolerant well mostly" The Globe and Mail 1 July, page A9

Wiseman N, 2007 In Search of Canadian Political Culture (University of British Columbia Press, Vancouver) 
Conditions of use. This article may be downloaded from the E\&P website for personal research by members of subscribing organisations. This PDF may not be placed on any website (or other online distribution system) without permission of the publisher. 